\title{
Os "Sem Religião" no Brasil: Juventude, Periferia, Indiferentismo Religioso e Trânsito entre Religiões Institucionalizadas
}

\author{
Marcelo Ayres Camurça*
}

\section{Resumo}

Este artigo visa compreender a dimensão que tomou a categoria "sem religião" no Brasil, a princípio um tipo classificatório do recenseamento governamental, que se tornou uma realidade social com implicações diretas nas interpretações sociológicas sobre o campo religioso brasileiro e os seus desdobramentos na sociedade maior. A partir de uma análise dos dados estatísticos, geográficos e sociais expostos nos últimos censos em torno dessa categoria, se procurará detectar as tendências de conduta (pós) religiosa, que esses novos atores propiciam: individualismo, trânsito, desinstitucionalização, múltipla pertença religiosa e indiferentismo religioso. Além disso, como esse novo ethos, em relação à religião, se espraia para uma população jovem, pobre e periférica, indicando um processo de avanço de modernidade e secularização, nesse meio, temperado, contudo, por um forte imaginário religioso que não abandona as mentalidades dos chamados "sem religião", numa continuidade com nossa tradição religiosa centenária.

Palavras-chave: "Sem religião". Juventude. Camadas populares. Autonomia. Trânsito religioso. Desinstitucionalização.

\section{Abstract}

This article aims to understand the dimension that took the category "without religion" in Brazil, initially a classificatory type of government census, which became a social reality with direct implications in the sociological interpretations of the Brazilian religious field and its unfolding in the larger society. From an analysis of the statistical, geographic and social data exposed in the last Censuses around this category, we will try to detect the trends of (post) religious behavior that these new actors favor: individualism, transit, deinstitutionalization, multiple ownership religious and religious indifferentism. Moreover, as this new ethos in relation to religion, it spreads to a young, poor and peripheral population, indicating a process of progress of modernity and secularization in this environment, tempered, however, by a strong religious imaginary

* Professor Titular da Universidade Federal de Juiz de Fora (UFJF), atuando no Programa de Pós-Graduação em Ciência da Religião (PPCIR). Bolsista de produtividade no CNPQ nível 02. 
that does not abandon the mentalities of called "without religion", in continuity with our centennial religious tradition.

Key-words: "No religion". Youth. Grassroots. Autonomy. Religious transit. Deinstitutionalization.

\section{Introdução}

Ao longo dos recenseamentos governamentais da população efetuados no Brasil nos últimos anos, dentro da questão acerca da religião dos cidadãos, vem se notando uma crescente visibilidade do que se chamou de "sem religião". Essa categoria é produto de uma autodeclaração dos respondentes entrevistados diante da pergunta formulada pelo recenseador, "qual sua religião ou culto?" contida no manual do IBGE (2010). Segundo a pesquisa de Rodrigues até a década de 1950, "sem religião" era uma categoria inexistente no censo, pois respostas negativas àquela pergunta sobre qual a religião dos recenseados eram computadas no registro "sem declaração". Apenas a partir do Censo de 1960 as respostas que rejeitavam possuir religião ou culto, foram categorizadas como "sem religião", ganhando existência enquanto expressão de um grupo de opinião (OLIVEIRA PEREIRA, 2002: 2 apud RODRIGUES, 2011: 51). Com um desacerto nas datas, a pesquisa de Nicolini baseando-se em informações anteriores, indica que "tal categoria teria aparecido em 1940, mas surge como temática em 1991” (MAGALDI, 2014 apud NICOLINI, 2017: 442).

Apesar dessa incompatibilidade na cronologia quanto ao estabelecimento da categoria "sem religião", em ambas as proposições, fica clara a ideia de que a partir de determinado momento - com certeza, fruto das transformações societárias e culturais que acometeram o país ${ }^{1}$ - a condição de ser "sem religião" passa a ser considerada como dado social relevante para instituições de análise abalizadas no país enquanto constitutiva da identidade de indivíduos no Brasil, que se declararam como tal. Inclusive em posicionamentos públicos, estatais e republicanos como em um recenseamento nacional. Da mesma forma, ambas as análises ressaltam o caráter de autodeclaração

1 Segundo Antoniazzi, os dados sobre o perfil religioso no Brasil, se somados a outros percebidos nos censos recentes (diminuição da natalidade, aumento dos casamentos sem legalização, aumento da escolaridade), apontam para uma "modernização de hábitos e crescimento do individualismo subjetivista" (2002: 87). De igual maneira, Novaes afirma que "com a diminuição da transferência religiosa intergeracional e com a dissociação entre vida sexual e casamento, modificam-se os padrões de moralidade e restringe-se o peso das autoridades religiosas", levando a uma situação de diversidade na realidade social (2013: 1.870). 
dessa categoria "sem religião", diferindo de uma constatação objetiva pelo recenseador, e se aproximando de outras (auto)declarações no Censo, como aquela sobre cor ou raça (RODRIGUES, 2012: 1.133). Com isso indicando, segundo autores, um perfil de autonomia do indivíduo e de "liberdade de vir a ser por si" (NICOLINI, 2017: 447), características de liberdade individual e de consciência, expressões da constituição da modernidade no país.

Este texto visa discutir, portanto, a partir dos indicadores sobre classe, renda, faixa etária e região, levantados nos censos quanto aos chamados "sem religião" e cotejados com outras pesquisas específicas a respeito de religião, juventude e sociedade no Brasil, as dimensões e tendências das mentalidades, comportamentos e valores que incidem no panorama religioso atual no país e seus rebatimentos na vida social mais ampla.

\section{Os "sem religião" nos censos governamentais de popula- ção no Brasil}

Esta categoria, inicialmente específica do contexto dos recenseamentos de população realizados pelo órgão governamental, o Instituto Brasileiro de Geografia e Estatística (IBGE), produzida por seus técnicos estatísticos para alocar respostas que não expressavam uma adesão religiosa, terminou extrapolando essa circunscrição e se apresentando como referência para análises sociológicas e antropológicas mais amplas sobre as mutações e tendências contemporâneas do panorama religioso do Brasil contemporâneo. ${ }^{2}$

Mas o que significa do ponto de vista sociológico, cultural e político, esse crescente e contínuo desgarrar-se de pertenças religiosas por homens e mulheres no país? Para muitos especialistas no tema, seria um equívoco afirmar que isso signifique um crescimento do ateísmo no país (RODRIGUES 2012: 1.135). Do total dos 15,3 milhões de indivíduos "sem religião" apontados no censo de 2010, apenas 615 mil declararam-se ateus $(0,32 \%)$ e 124 mil agnósticos (0,07\%) (NOVAES 2013: 175; RODRIGUES, 2012 : 1.138). Para Antoniazzi, no caso do Estado do Rio de Janeiro, o Estado da federação com maior concentração de "sem religião", numa pesquisa realizada pelo CERIS (ONG de matiz católica que assessora a CNBB) na área metropolitana desse Estado, à época do Censo de 2000, foram encontrados

Para uma compreensão maior a respeito do processo de alargamento de indicadores estatísticos sobre religião dos censos em realidades sociais e categorias sociológicas, inclusive objeto de disputas dentro do campo religioso brasileiro por legitimidade e prestígio ver Camurça 2014: 08-18. 
$16,7 \%$ de entrevistados que se declararam "sem religião", que, no entanto, afirmavam acreditar em Deus ou força superior contra apenas 1,2\% que se declararam ateus (2002: 88). Também Regina Novaes destaca que pesquisas específicas sobre a juventude, como o "Projeto Juventude do Instituto cidadania" e a pesquisa "Perfil da Juventude Brasileira" revelaram que 10\% dos jovens que se declararam como "sem religião" disseram acreditar em Deus e apenas 1\% serem ateus ou agnósticos" (2006: 139).

Numa série histórica dos indicadores estatísticos relativos às declarações de "sem religião", pode-se constatar o avanço e a crescente visibilidade que adquiriu o conjunto dos indivíduos que se declaram enquanto tal. De 0,5\% em 1960, 0,8\% em 1970, 1,6\% em 1980, 4,8\% em 1991, 7,4\% em 2000 , alcançou-se no último recenseamento de 2010 , o percentual de $8 \%$, perfazendo um total de 15,3 milhões da população brasileira. No censo de 1991, essa categoria experimentou um crescimento de 3,1\% em relação ao decênio anterior e no censo de 2000 um crescimento de 2,7\% (RODRIGUES, 2012: 1.134; 2011: 51).

Na última década recenseada, de 2000 a 2010, contudo, o crescimento dos "sem religião" se deu em um ritmo menor, de 7,4\% para $8 \%$, em números absolutos da população, de 12,3 milhões para 15,3 milhões (IBGE, 2012: 90). Com isso abriu-se um debate entre analistas sobre um possível teto-limite para o crescimento dos "sem religião" em um país de "grande tradição religiosa"” (lembrar que se somando todas as declarações dos "com religião", chega-se à cifra dos quase $92 \%$ ). No entanto, afora o dado estatístico do crescimento menor dos sem religião em relação ao crescimento das décadas anteriores e em relação ao crescimento mais expressivo dos evangélicos, isso não significa, em minha opinião, que as porcentagens estejam apontando um "limite" para o crescimento dos "sem religião". Pois, compreendendo os indivíduos "sem religião" como "religiosos sem instituição" isso não discreparia da "tradição religiosa" do país, eles apenas expressariam, no Brasil, o processo de "desfiliação religiosa" relacionado a uma (pós) modernidade religiosa (CAMURÇA, 2006: 44-45) já consagrada na frase de Gracie Davies "believe but not belong". E podemos acrescentar ainda, com os índices trazidos na pesquisa de

\footnotetext{
3 Declaração dos pesquisadores Gustavo Givisiez do Departamento de Geografia da UFF e Claudio Crespo do IBGE de que a tendência de crescimento dos sem religião "pode ter chegado a um limite", com o argumento de ser o Brasil um "país de tradição religiosa" e pelo fato de haver uma "reação das religiões, como o fato dos pentecostais crescerem" (O Globo, 30/06/12).
} 
Marcos Nicolini, que numa perspectiva histórica de longo curso, verifica-se a tendência crescente dos "sem religião" acompanhando os indicadores de modernidade, que, em 1960, eram 0,5\% e, em 2012, chegam a 8\%, perfazendo "um crescimento de $1508,0 \%$ descontando o crescimento vegetativo da população" (NICOLINI, 2012: 25). Da mesma forma, Novaes reitera que na longa duração o crescimento dos "sem religião" é significativamente expressivo: "os sem religião eram $0,2 \%$ no censo de 1940. Em cinquenta anos, houve crescimento de 52\% (2006: 137).

Do ponto de vista geracional, em sua maioria, são jovens com idade média de 26 anos. Dentro dessa média, estes se distribuem da seguinte forma: 9,30\% entre 15 e 19 anos, $10,03 \%$ entre 20 e 24 anos e 9,50\% entre 25 e 29 anos. Logo, não são predominantemente, nem "jovens-adolescentes", nem “jovens-adultos”, mas “jovens-jovens”, segundo a classificação da Secretaria Nacional da Juventude e Conselho Nacional da Juventude, órgãos governamentais (NOVAES, 20133: 180-181). E se a cifra total dos "sem religião" foi de $8 \%$ na relação com a população, no último censo, se tomarmos a faixa etária de 15 a 29 anos, esse número aumenta para 9,5\% (NOVAES 2013: 175).

Outro dado, extremamente elucidativo, da condição dos "sem religião" sublinhado por mim em texto anterior, é o de que estes se expandem justamente nas mesmas áreas geográfico-sociais onde crescem os evangélicos: as zonas de chegada de migração interna brasileira, nas periferias das grandes metrópoles e fronteiras de ocupação mineral e agrícola das regiões do norte e centro-oeste do país (CAMURÇA, 2013:66). Denise Rodrigues, nas suas pesquisas, corrobora com minha constatação, quando afirma que os "sem religião" tinham "como vizinhos, os evangélicos, concorrentes deles" em termos de representações percentuais (2012: 1.139). Ainda poderíamos constatar que no quesito de presença na juventude, índice que indica a vitalidade e o potencial de crescimento de um segmento, ambos evangélicos e "sem religião" se caracterizam por possuir maiores concentrações de seus extratos nessa faixa etária, os evangélicos tendo como idade média 27 anos e os "sem religião", uma idade média de 26 anos (IBGE, 2012: 99). A pesquisa "Jovens do Rio", coordenada por Novaes e Mello em 2002, indica que nos extratos mais pobres dessa juventude metropolitana, "dois fenômenos se destacaram: mais jovens de declararam evangélicos pentecostais que católicos (...) e quase 1/3 deles se declararam sem religião" (NOVAES, 2006: 145).

Devido à falta de uma configuração institucional que agregue esses indivíduos, na sua maioria jovens que se declaram "sem religião", as pesquisas 
e análises sobre o fenômeno detectam que estes se encontram dispersos, não se constituindo enquanto um grupo com identidade homogênea, ou mesmo que partilhem de uma "unidade de crenças" (NICOLINI, 2017: 446). Possuem como características gerais, segundo essas pesquisas e análises, de um lado, uma postura de indiferentismo e secularização que se traduz na sua falta de compromisso para com as instituições religiosas, e de outro lado, mantêm crenças e/ou espiritualidades independentes dessas instituições, embora estas ainda sejam uma referência para um trânsito por entre elas, sem se fixar, contudo, a nenhuma. Nesse sentido, podemos dizer como Regia Novaes que são jovens "religiosos sem religião" (2006: 137); uns possuidores de um imaginário religioso eclético que se utiliza, para consumo interno próprio, de elementos das várias religiões que se deparam e interagem; e outros, embora com esse imaginário religioso eclético, sem qualquer frequência, nem trânsito por entre as religiões institucionais, devido à "falta de tempo" e total desinteresse, absorvidos pelas dinâmicas do cotidiano, conforme tipologia estabelecida por Sílvia Fernandes para a sua análise dos "sem religião" (IHU On Line, 07/10/12).

Embora essa divisão em duas categorias, os "errantes por entre as religiões" e os "indiferentes às religiões", corresponda em um grau bastante consistente à realidade sociocultural dos "sem religião" (e vão servir ao esquema de apresentação, análise e conclusão que adotarei neste texto), em muitas observações empíricas pode-se assistir articulações e combinações entre estas duas posturas enquanto ethos e prática dos jovens "sem religião". $\mathrm{Na}$ pesquisa de Doutorado de Ana Maria Stephan entre os jovens do bairro popular Dom Bosco, na cidade de Juiz de Fora, no local conhecido como "chapadão", esses jovens de periferia não vivenciam pertenças às igrejas, templos ou terreiros, nem práticas religiosas regulares em suas vidas, nem mesmo visitas ou circulações entre as religiões existentes na região, a despeito de dizerem possuir "experiências religiosas" e de empregarem léxico e imagens religiosas como forma de lidar com percalços e tribulações que ocorrem nas suas vidas (2013: 99). Embora possuindo, nos dizeres da autora, uma "poética" de referências transcendentes: "proteção divina", “ajuda de Deus" para os perigos da lida diária, demonstram um completo alheamento em relação às instituições religiosas, como nestes depoimentos: "sem tempo prá escutar o pastor", "perda de tempo", "bobagem", "atraso de vida" e "preocupado em arrumar emprego" (STEPHAN, 2013: 105-107; 132-133). Podemos estar assistindo aqui, o que eu, Léa Perez e Fátima Tavares em pesquisa sobre os 
jovens em Minas Gerais, na experiência geracional desses jovens, chamamos de "modulação", entre sua sensibilidade religiosa e as referências culturais profundamente entranhadas no seu estilo de vida (esporte, lazer, sexualidade, mídia, internet, consumo etc.) (CAMURÇA, PEREZ, TAVARES, 2009: 191-200). Da mesma forma, entre os jovens "sem religião" das pesquisas de Nicolini e Stephan existe uma modulação entre referências religiosas e sua autonomia de vida, por fora das instituições religiosas e de seus formatos eficazes de ritos e códigos.

\section{Perfil social e localização geográfica dos (jovens) "sem religião"}

Consolidada no censo 2010, a informação de que os "sem religião" são um extrato majoritariamente jovem, antes de este censo apresentar novos dados sobre perfil social dos "sem religião", visualizava-se esse segmento como composto de indivíduos: jovens sim, mas situados nas camadas médias urbanas com alta escolaridade e renda. Aqui talvez uma influência da pesquisa pioneira de Regina Novaes sobre juventude e religião entre universitários (1994: 62-74), que abriu caminho para outras num escopo maior (STEIL e HERRERA, 2001: 09-36). Também Rodrigues destacou a ideia predominante que associava a descrença religiosa a grupos mais intelectualizados e com melhor situação econômica (2012: 1.139).

Porém, o censo 2010 ampliou e redimensionou a configuração dos jovens "sem religião", ${ }^{4}$ revelando que $47,1 \%$ deles são negros ou mestiços e $59,2 \%$ têm um ganho correspondente a um salário mínimo. Enfim, são, na sua maioria, homens, jovens com idade de 16 a 29 anos, solteiros, negros e mestiços, com baixa instrução, emprego instável e salários baixos, vivendo nas periferias (NOVAES, 2013). Da mesma forma, a pesquisa de Nicolini para os "sem religião" da cidade de São Paulo, concentrados no bairro de Itaquera, aponta para um segmento com maioria negra, com menos de 30 anos de idade, com renda de mais de dois salários mínimos e com ensino fundamental completo e médio incompleto (2017: 453).

Geograficamente, os "sem religião" têm sua maior percentagem localizada nas zonas de migração interna do país: periferia das grandes metrópoles

4 Denise Rodrigues aponta que já no censo de 2000, os "sem religião" eram homens jovens entre 16 e 30 anos de idade, pretos ou pardos, com baixa instrução e emprego modesto, residentes nas periferias das grandes cidades do Rio de Janeiro, São Paulo, Recife e Salvador (2012: 1.139). 
e áreas de concentração urbana do litoral brasileiro (Rio, Recife, Salvador); assim como, nas fronteiras de ocupação agrícola e mineral do norte e centro-oeste do país (Amazonas, Pará, Mato Grosso, Goiás) (CAMURÇA 2013: 66). O Sudeste $\operatorname{com} 8,96 \%$ e o Centro-Oeste com $8,42 \%$ concentram no país, o maior número dos "sem religião", seguidos do Nordeste com 8,29\%; ao passo que o Sul, com 4,82\%, tem o menor índice (RODRIGUES, 2012: 1.139). O Estado do Rio de Janeiro é aquele que aglutina o maior percentual dos "sem religião": 16\%, o dobro de sua média nacional, mas também os Estados do norte do Brasil como Rondônia (14,34\%) e Roraima (12,8\%) possuem taxas muito altas também acima da média (RODRIGUES, 2012: 1.139). O que confirma a ideia de que a dinâmica de crescimento dos "sem religião" se dá nas periferias das metrópoles e nas fronteiras da migração interna do Brasil.

Constata-se que o seu crescimento vem de uma diminuição da transferência religiosa intergeracional, ou seja, da pouca capacidade dos pais (católicos, mas também evangélicos) de reproduzirem sua religião nos filhos, ou seja, como assevera Novaes, um fenômeno de "descontinuidade com as religiões de seus pais” (2013: 178). Denise Rodrigues levanta a hipótese de que os "sem religião" são produto de um processo de desconversão em relação às instituições religiosas, tanto à Igreja Católica quanto às igrejas evangélicas, em razão do excesso de normas rígidas estabelecidas por essas igrejas, que se chocam com o desejo de liberdade e de experimentação por parte dessa juventude (2012: 1.142).

Por todo o já exposto, somos levados a concordar com a instigante formulação de Nicolini de que os "sem religião" são "duplamente periféricos", porque concentrados nas periferias das grandes metrópoles (no caso de seu estudo: São Paulo) e também nas periferias das religiões (2017: 438).

\section{Os "sem religião", sua self religiosity e sua relação com as religiões institucionais}

Esses jovens "sem religião" mantêm uma crítica acerba às religiões institucionais, a quem acusam de "intolerância”, "hipocrisia', "dissonância entre pregação e prática" ou "incoerência entre discurso e comportamento" (NICOLINI, 2017: 475). Veem na competição e conflito entre as religiões pelo monopólio da verdade, um motivo para o seu afastamento da adesão única. Por isso enveredam em um pragmatismo religioso, distanciando-se das religiões e seus cleros, que perdem a autoridade de prescrever normas morais para esses jovens (NICOLINI, 2017: 477). Constroem assim a sua 
self religion (auto-religião), que é uma síntese pessoal das crenças religiosas difundidas no país.

Dessa maneira, não pertencer a um agrupamento religioso não significa que o indivíduo seja descrente, sugerindo mais que ele possua uma religiosidade privada. Nesse sentido é que Regina Noves defendeu a expressão "religiosos sem religião", para definir essas pessoas que cultivam uma religiosidade de caráter pessoal, sem possuir, contudo, vínculos institucionais (2006: 137).

Para essa autora, o fenômeno sociocultural-simbólico dos jovens "sem religião" enquanto uma nova forma de ser religioso, sem pertença formal, se deve às transformações societárias que conjugam (contraditoriamente) a perda da capacidade normativa das religiões nesse segmento sociogeracional com a manutenção de sua influência de forma livre para as experimentações juvenis (2006: 135). Tudo isso espelha uma reflexão à maneira de Hervieu-Léger que retomarei de forma mais constante na conclusão do texto. Desse modo, segundo Novaes, "os jovens estão menos submetidos a tradicionais autoridades religiosas, [e] vivem um momento de desaparecimento de fronteiras simbólicas (...) entre religião e novas crenças seculares e para-religiosas" (2006: 135).

Desembaraçar-se de uma pertença exclusiva a uma religião, no entender dessa autora, pode gerar um "campo de possibilidades" para essa geração com "virtualidades distintas" (NOVAES, 2006: 141). Uma primeira seria a de um "estado provisório", um interregno entre o abandono de uma religião e a adesão a outra; e uma segunda, um "estado permanente", que legitima "socialmente a possibilidade de ser religioso sem religião" (2006: 141). Em outro texto, ela retoma a mesma ideia: “'não ter religião' abre espaço potencial para (re) iniciar adesões institucionais quanto para 'interagir' - sem vigilância eclesiástica - com pessoas de outras religiões” (NOVAES, 2013: 186).

Essa condição de independência em relação às religiões institucionais gerou várias modalidades de ser "sem religião", observadas, resenhadas e tipificadas por pesquisadores. Rodrigues classificou os "sem religião" em quatro subgrupos, que expressam, no entanto, com suas ênfase e matizes, uma característica semelhante, que é a de possuir uma religiosidade própria, por fora da pertença à religiões formais, nutrida, entretanto, por ideias e práticas religiosas provenientes dessas religiões. São eles: 1) os que creem em uma força divina, mas sem pertença religiosa; 2) os integrantes de grupos místicos/esotéricos que não se consideram religião; 3) os que realizam um trânsito entre as religiões estabelecidas sem se vincular a qualquer delas; 4) 
os consumidores de bens religiosos como produtos terapêuticos (RODRIGUES 2012: 1.137). Da mesma forma, Novaes, a partir dos dados da pesquisa "Jovens do Rio", que ela coordenou com Cecília Mello, em 2002, também estabelece uma tipologia dos "sem religião", na mesma perspectiva: "a) forte disposição para o trânsito religioso e para novas combinações sincréticas; b) diminuição da transferência religiosa intergeracional e ênfase na escolha individual (...) c) ampliação das possibilidades para o desenvolvimento de religiosidade sem vínculos institucionais" (2006: 145).

\section{Os "sem religião", indiferentismo religioso e secularização}

Além da crítica contundente às religiões institucionalizadas - que, como discuti no item anterior, não impediu os jovens "sem religião" retirarem, das últimas, elementos simbólicos para compor sua própria religiosidade - outro fator importante contribuiu para a desfiliação religiosa desses jovens. Estou aqui falando da força de atração que a dinâmica secularizadora da sociedade (necessidades econômicas, de sobrevivência, de lazer etc.) exerce sobre os indivíduos, envolvendo-os numa contínua atividade imanente e gerando aquilo que Zigmunt Bauman se referiu como a "autosuficiência humana" (1998: 212). Nesse particular, prevalece uma atitude pragmática que rejeita qualquer tipo de inquietação com o post-mortem, premido pelos "problemas (...) sobre os quais se pode fazer algo" (1998: 212-213).

Em texto anterior, referi-me à força imperiosa da secularização que faz que os indivíduos se voltem para "as coisas do mundo" (2013: 82). E no caso dos "sem religião" brasileiros, as dificuldades socioeconômicas com a migração e fixação nas periferias dos conglomerados urbanos ou nas fronteiras de expansão geográfica, e seu consequente enfrentamento, não favorecem necessariamente a uma adesão religiosa, mas podem levar ao indiferentismo religioso (2013: 82). Rodrigues transcreve o relato de seus entrevistados para quem "falta tempo para freqüentar rituais religiosos" devido ao acúmulo de tarefas na vida profissional e doméstica; fato que termina por gerar uma desmotivação para o segmento de atividades religiosas: "falta vontade de engajar-se” (2013: 1.145). Também a pesquisa de Barrera, sobre a presença religiosa nas periferias do município de São Bernardo do Campo/SP, constata uma diminuição da importância da religião na vida dos moradores das favelas (2010: 09) e o consequente aumento dos que se declaram "sem religião" (2010: 10) e que seguem "acreditando em Deus", mas "sem freqüência à igreja" (2912: 50). 
A expansão da secularização por instâncias e instituições da vida social, impondo sua lógica da racionalização e a organização tecnicocientífica, conduz em um segundo momento a uma secularização das mentalidades. $\mathrm{Na}$ acepção de Peter Berger, "o palco original da secularização (...) foi a área econômica (...) um 'território livre' com relação à religião (...) a secularização partiu daí "para fora" na direção de outras da sociedade ${ }^{5}$ (1985: 141). Na análise de Rodrigues, esse processo possibilita no caso dos "sem religião" no Brasil, o surgimento de uma "secularização relativa de consciência acompanhada por uma crise de credibilidade nas instituições religiosas" (RODRIGUES, 2012). Em outro texto, a mesma autora vai se referir a uma "secularização subjetiva" que não necessariamente desliga o indivíduo da crença, mas o retira nitidamente das instituições religiosas" (2011: 53).

Mas em que consistiria essa "secularização de consciência" ou "subjetiva", que atinge agora de forma veemente também os pobres e habitantes das periferias brasileiras? Ela pode se resumir numa crença pessoal em Deus, numa crença pragmática em "fazer o bem" sem aprisionamento a doutrinas, teologias ou igrejas, em uma referência moral geral a um cristianismo difuso, com citações à Bíblia, Deus, Jesus e por fim a atribuição dos êxitos na vida a uma interferência divina (NICOLINI, 2017: 456-472).

\section{Considerações Finais}

De toda esta compilação de dados estatísticos, geográficos e sociológicos, assim como, de análises das características e tendências dos "sem religião", no panorama religioso e social do Brasil atual, podemos, à guisa de conclusão, apontar algumas sugestões.

Uma primeira que se destaca, é a de que para largas camadas da população brasileira que vivem nas zonas de periferia e pobreza, não apenas as religiões, particularmente as dos evangélicos, mas também os "sem religião" passam ganhar seus "corações e mentes" e oferecer sentido e valor para as suas vidas. Sua expressiva presença (ao lado dos evangélicos) entre os desfavorecidos coloca outra alternativa em jogo para a organização social, cultural e simbólica das camadas populares. Afinal, como na jocosa indagação de Dario

\footnotetext{
5 Berger vai dizer que devido ao caráter de "tendência global" da secularização, "os conteúdos religiosos tendem de um modo geral a se modificar numa direção secularizante", como nos casos do "protestantismo liberal e judaísmo" que promovem "a exclusão de (...) quase todos os elementos 'sobrenaturais da tradição religiosa, e [estruturam a sua] legitimação (...) em termos puramente secularizantes” (1985: 157).
} 
Pablo Barrera na contracapa do livro de Marcos Nicolini: "Não era religião, coisa de pobre?", o que os recentes dados sobre a afinidade entre periferia e "sem religião" parecem indicar é que religião é algo "que se pega", mas também "que se larga", segundo a mesma afirmação de Barrera.

Entretanto, a forma dispersa e não homogênea que caracteriza a inserção social desses indivíduos poderia indicar uma fragilidade quanto à possível formação de grupos de pressão e de identidade social nesse meio, fruto de sua postura de afastamento das religiões; caracterizando o que classicamente já se chamou de "individualismo moderno", agora aqui no seio de pobres e periféricos. Porém, a ousada interpretação de Nicolini logra ver nessa atitude uma postura de "liberdade e autodeterminação", na atitude "de se autodeclarar como tal" (2017: 441). Isso em contraposição a uma lógica "essencialista ou nominalista", a uma "identidade fornecida externamente, heterônoma" que um pertencimento naturalizado às religiões conseguiu impor secularmente a essas populações (2017: 439,441). E o autor vai mais adiante, numa afirmação, que no meu entender é ainda precoce como indicador social, mas que como hipótese é provocativa; a de que essa declaração e atitude de vida como "sem religião" entre classes populares, pode funcionar como um "contra poder resistente e não violento" (2017: 338), na medida em que se confronta de maneira pacífica ao discurso dominante da adesão e pertença religiosa naturalizada, podendo formar, no seu entender, "novas relações (...) de reconhecimento mútuo de indivíduos livres" nas periferias (2017: 449). Rodrigues, na mesma direção, também relaciona os "sem religião" com as "liberdades mais reivindicadas pelo individualismo moderno: a de consciência e a de expressão" (2011: 49). E saúda a disposição de certos indivíduos para assumir uma "condição de religiosidade independente de instituições tradicionais" (2011: 55); pois do seu ponto de vista, essa atitude se revela como "sinal irrefutável de ampliação de consciência dos direitos humanos e do exercício pleno de liberdades individuais” (2011: 55).

Um leitor mais atento poderia observar uma contradição nos meus argumentos, pois, por um lado afirmei, em item anterior, a prevalência de um determinismo econômico/social da luta pela sobrevivência entre os segmentos pobres, migrantes e periféricos da população como causa de sua "falta de tempo" para a religião, e aqui afirmo a condição desses "sem religião" como uma tomada de posição autônoma e autoconsciente. Admito essa contradição como parte da tensão entre forças distintas que atuam para a conformação desse extrato da população a partir de causas "materialistas" e "idealistas". 
Em meu favor, diria que iniciativas tomadas enquanto expressões de liberdade de consciência estão sempre assentadas numa base de condições sociais e econômicas determinadas; e de outro lado, que não necessariamente as causalidades socioeconômicas se reproduzem enquanto um "círculo férreo" impondo uma situação previsível, mas que a iniciativa criativa do sujeito irrompe alterando e inovando o curso dessa realidade.

Uma segunda sugestão que apresento expõe outra tensão, aquela que confronta duas tendências que se desenvolvem no cenário religioso brasileiro, ambas verificáveis, mas contrapostas entre si. Uma primeira tendência aponta - para este país com cerca de $92 \%$ da população aderente a um credo religioso - que iniciativas de secularização e rejeição a um pertencimento religioso, tem de necessariamente se articular e negociar com essa condição religiosa majoritária. E, uma segunda tendência, destaca o papel de brecha e cunha que o irromper dos "sem religião" cria como alternativa secular no seio do tecido religioso majoritário da sociedade brasileira.

No primeiro caso, devido ao caráter extremamente religioso da sociedade brasileira, em termos de imaginário, valores e práticas sociais, o nosso processo de secularização não exerceu o poder de recalque sobre a dimensão da religião, como no paradigma clássico. Sirvo-me aqui, como inspiração teórica mais ampla para a interpretação desse fenômeno, da reflexão de Danièle Hervieu-Léger (CAMURÇA, 2003: 249-270), para quem, o que ocorre na contemporaneidade é mais uma recomposição do papel da religião do que uma perda de sua influência. Para essa autora, "a secularização (...) não se resume no processo de evicção social e cultural da religião (...) A secularização é um processo (...) que combina a perda de controle dos grandes sistemas religiosos (...) e a recomposição (sob uma nova forma) das representações religiosas" (1996: 15-16). A isso Hervieu-Léger chamou de "desregulação institucional"; ou seja, a atual incapacidade do controle das consciências pelas formas religiosas institucionalizadas; aliada ao surgimento de novas formas de crenças que circulam e se apropriam dos signos religiosos das religiões tradicionais, numa contínua recuperação e reinterpretação (1996: 20). Aqui, nada mais apropriado para interpretar o caso dos "sem religião" no Brasil.

Talvez, devido a isso, que muitas análises sobre os "sem religião" não os coloquem apartados do campo religioso brasileiro, mas como expressão de uma "recomposição" no sentido empregado por Hervieu-Léger, que se opera nele, gerando uma reacomodação dentro do seu cenário. Nesse sentido, é que se compreende a afirmação de Regina Novaes de que “"ser” (ou 
'estar') sem religião se inscreve como uma nova posição possível no campo religioso" (2013: 186). A atestar essa afirmação dela, a corriqueira análise dos pesquisadores sobre as religiões no Brasil, entre estes, eu mesmo, de que os "sem religião" se encontram computados na terceira posição dentro das análises censitárias sobre o campo religioso, com $8 \%$ de aderentes abaixo dos $64,6 \%$ dos católicos e dos 22,2\% de evangélicos e bem acima dos 2\% de espíritas e de "outras religiosidades” com 2,7\% (CAMURÇA, 2013: 63-67).

No segundo caso, o surgimento de surtos e investidas de secularização e laicismo - da qual a existência dos "sem religião" é uma de suas expressões - por sobre essa base religiosa sedimentada pode estar sugerindo uma alternativa secular, que paulatinamente está se colocando à configuração religiosa majoritária. Antonio Flavio Pierucci, ainda para o Censo de 2000, já sublinhava que o fenômeno de transição a ser observado era que o grupo dos "com religião" começa a se desfalcar, "pois no caso do Rio de Janeiro, não foi só o aumento evangélico $(21,1 \%)$, mas também os do sem religião $(15,5 \%)$ que fez o catolicismo despencar até seu ponto mais baixo" (PIERUCCI, Folha de São Paulo, 20/12/2002). Da mesma forma, Rodrigues, aponta como hipótese forte, que a crise católica redundou tanto em crescimento evangélico, mas muito expressivamente também dos "sem religião". Sua pesquisa indica que 70\% dos "sem religião" foram criados em ambiente religioso e com pertença religiosa (apenas 7\% foram criados já como "sem religião") e 59\% destes vieram do catolicismo (2012: 1.140).

Embora, para Regina Novaes, o que chamei de duas vertentes que envolvem os "sem religião" não possam ser separadas. E ela defenda em seus textos esse ponto de vista muito enfaticamente. Pois para ela, colocar a problemática dos "sem religião" dentro de um esquema explicativo rígido da "desfiliação" ou "des-conversão" em relação ao universo das religiões; onde se dividem tipos fixos como "pertença x não-pertença", termina por não contemplar a dinâmica das experimentações e dos arranjos em termos de religiosidade efetuados por esse segmento juvenil da população tanto em relação às religiões institucionais quanto a outras instâncias da sociedade como o meio da web e da internet (NOVAES 2012: 188-189).

Embora eu também, por meu lado, tenha apresentado aqui neste texto momentos de diluição dessas tendências em movimentos de permeabilidades e porosidades, prefiro concluir este texto, destacando diferencialmente estes dois "tipos" de "sem religião" (os "errantes" e os "indiferentes"). Contudo, ressalto a existência de uma terceira tendência entre os dois, que é a cons- 


\section{Os "Sem Religião" no Brasil: Juventude, Periferia, Indiferentismo \\ Religioso e Trânsito entre Religiões Institucionalizadas}

tante "afinidade eletiva" que os liga e os imbrica um no outro. Ao fazer isso, resgato outra imagem recorrente também em textos de Novaes sobre os "sem religião", que é aquela que os mostra como situados na interface entre "ventos secularizantes" e "experimentações" com o Sagrado, que marca o “espírito" de "nossa época” (NOVAES, 2006: 137).

\section{Referências}

ANTONIAZZI, Alberto. As religiões no Brasil segundo o Censo de 2000. Magis: cadernos de fé e cultura (especial), n. 1, ago., p. 83-109.

BARRERA RIVERA, Dario Pablo. Pluralismo religioso e secularização: pentecostais na periferia da cidade de São Bernardo do Campo no Brasil. Estudos de Religião, 2010, p. 50-76.

Religião e desigualdades sociais no Município de São Bernardo do Campo: estudo comparativo de grupos em dois bairros de condições sociais e econômicas opostas. In: Dario P. B. Rivera (Org.). Evangélicos e periferia urbana em São Paulo e Rio de Janeiro: estudos de sociologia e antropologia urbanas. Curitiba: CRV, 2012, p. 17-64.

BAUMAN, Zigmunt. Religião pós-moderna? O mal-estar da pós-modernidade. Rio de Janeiro: Zahar, 1998, p. 205-245.

BERGER, Peter. O Dossel Sagrado: elementos para uma teoria sociológica da religião. São Paulo: Paulus, 1985.

CAMURÇA, Marcelo. O Brasil religioso que emerge do Censo de 2010: consolidações, tendências e perplexidades. In: Teixeira Faustino, Menezes Renata (Orgs.). Religiões em Movimento: o Censo de 2010. Vozes: Petrópolis, 2013, p. 63-87.

A Religião e o Censo: enfoques metodológicos - uma reflexão a partir das consultorias do ISER ao IBGE sobre o dado religioso nos Censos. Comunicações do ISER - Religiões em Conexão: números, direitos, pessoas. Christina Vital, Renata Menezes (Orgs.), n. 69, ano 33, 2014, p. 8-17.

. A realidade das religiões no Brasil no Censo IBGE-2000. In: Faustino Teixeira e Renata Menezes (Orgs.). As Religiões no Brasil: continuidades e rupturas. Petrópolis: Vozes, 2006, p. 35-48.

A sociologia da religião de Danièle Hervieu-Léger: entre a memória e a emoção. In: Faustino Teixeira (Org.). Sociologia da Religião: enfoques teóricos. Vozes: Petrópolis, 2003, p. 249-270.

CAMURÇA, Marcelo, PEREZ, Léa, TAVARES, Fátima. Ser jovem em Minas Gerais: religião, cultura e política. Belo Horizonte: Argvmentvm, 2009.

FERNANDES, Sílvia. A (re) construção da identidade religiosa inclui dupla ou tripla pertença. IHU On Line, 07/10/12 [Disponível em http://www.ihu.unisinos.br/entrevistas - Acesso em 31/10/2017]. 
HERVIEU-LÉGER, Danièle. La religions des eupéens, modernité, religion, secularization. In: Gracie Davie \& Danièle Hervieu-Léger (éds.). Les identités religieuses en Europe. Paris: La Découverte, 1996, p. 9-23.

INSTITUTO BRASILEIRO DE GEOGRAFIA E ESTATÍSTICA (IBGE). Manual do recenseador: pesquisa de avaliação da cobertura. Rio de Janeiro: IBGE, 2010.

Censo Demográfico 2010 - Características gerais da população, religião e pessoas com deficiência. Rio de Janeiro: IBGE, 2012, p. 89-105.

NICOLINI, Marcos Henrique de Oliveira. Religião e Cidade - a precariedade dos sem religião como contestação da exclusão social em São Paulo (Projeto de Qualificação Doutoral). São Bernardo: UMESP, 2012.

. Religião e Poder Civil, arranjos e resistências. CRV, Curitiba, 2017.

NOVAES, Regina. Jovens sem religião: sinais de outros tempos. In: Teixeira F., Menezes R. (Orgs.). Religiões em Movimento: o Censo de 2010. Vozes, Petrópolis 2013, p. 175-190.

Os jovens, os ventos secularizantes e o espírito do tempo. As Religiões no Brasil: continuidades e rupturas. Petrópolis: Vozes, 2006, p. 135-160.

. Religião e Política entre os alunos de Ciências Sociais. Comunicações do ISER, n. 45,1994 , p. $62-74$.

RODRIGUES, Denise dos Santos. Os sem religião nos censos brasileiros: sinal de uma crise de pertencimento institucional. Horizonte, v. 10, 2012, p. 1.130-1.152.

. Liberdade de afirmar-se "sem religião", reflexo de transformações no Brasil contemporâneo. Plura: revista de estudos de religião, v. 11, 2011, p. 49-64.

STEIL, Carlos Alberto, HERRERA, Sônia. Religião e Política entre alunos de Ciências Sociais: um perfil. Debates do NER, n. 2, 2001, p. 9-36.

STEPHAN, Ana Maria. Adolescentes e a poética das religiosidades: reflexões sobre (des) crenças e invenções. Juiz de Fora, Tese de Doutoramento, PPCIR/UFJF, 2013.

\section{REFERÊNCIAS DE PERIÓDICOS E REVISTAS}

FOLHA DE SÃO PAULO. “A encruzilhada da Fé”, 20/12/2002.

O GLOBO. "Pela primeira vez, o número de católicos caiu", 30/06/2012. 